\title{
Autologous hematopoietic stem cell transplantation with concomitant SARS-CoV-2 infection
}

\author{
Hanna A. Knaus ${ }^{1}$ (1) $\cdot$ W. Rabitsch ${ }^{1} \cdot$ N. Buchtele ${ }^{1} \cdot$ J. Cserna ${ }^{1} \cdot$ P. Wohlfarth ${ }^{1}$ \\ Received: 12 September 2021 / Accepted: 22 September 2021 / Published online: 13 October 2021 \\ (c) The Author(s), under exclusive licence to Springer-Verlag GmbH Germany, part of Springer Nature 2021
}

Keywords SARS-CoV-2 · COVID-19 · Hematopoietic stem cell transplantation · Pre-engraftment $\cdot$ Leukopenia · Lymphopenia

\section{Dear Editor,}

Coronavirus disease (COVID-19) in patients undergoing hematopoietic stem cell transplantation (HSCT) is a great concern to transplant centers around the world. While data on COVID-19 in HSCT recipients after stable engraftment is constantly growing [1-4], only limited data on the impact of COVID-19 during conditioning therapy or the pre-engraftment phase is available with only three adult cases reported as of September 2021. This data is important to help clinicians prepare for such occurrences and to put plans and strategies into place for possible COVID-19 in this highly vulnerable patient population. Therefore, we report the case of a patient with SARS-CoV-2 infection detected during conditioning chemotherapy before HSCT and review previous reports of COVID-19 in severe neutropenia shortly before/after HSCT:

A 33-year-old man with relapsed testicular non-seminomatous germ-cell tumor was admitted to receive his second HSCT as part of a tandem autologous HSCT [5]. He had completed his first HSCT without any unexpected complications and had been discharged 12 days earlier. The patient was in overall good condition (ECOG performance status 0 ) and without any comorbidity (HCT-CI: 0 points).

Upon admission, the patient had no fever or cough and a nasopharyngeal swab was negative for SARS-CoV-2 using RT-PCR technique. The start of conditioning chemotherapy was postponed due to a febrile UTI but 4 days later, after empiric antibiotic treatment and clinical improvement,

Hanna A. Knaus

hanna.knaus@meduniwien.ac.at

1 Hematopoietic Stem Cell Transplantation Unit, Department of Medicine I, Medical University of Vienna, Währinger Gürtel 18-20, 1090 Vienna, Austria myeloablative conditioning consisting of carboplatin $500 \mathrm{mg} / \mathrm{m} 2$ and etoposide $500 \mathrm{mg} / \mathrm{m} 2$ was started [5]. On 'day minus 4' after the patient had already completed 2 of 3 days of conditioning chemotherapy, the patient had another swab taken as part of our unit's routine weekly RTPCR-based testing. This swab was now positive for SARS$\mathrm{CoV}-2$ with a RT-PCR cycle threshold (Ct) value of 13.5 but the patient continued to be asymptomatic. Variant testing was indicative of the B.1.1.7 SARS-CoV-2 alpha variant.

A BMT board decision was made to not administer the last day of conditioning chemotherapy. To protect other patients and staff, the HEPA filter positive pressure lock systems of the patient's room was turned off for the time of required isolation. Further, an infectious disease consult recommended the use of remdesivir [6], which was started the following day for a total of 9 days and was well tolerated by the patient. A chest radiograph (CXR) showed no infiltrates or other SARS-CoV-2 specific alterations (Fig. 1A).

Further, all staff and other patients admitted to our unit during this time were required to undergo RT-PCR-based SARS-CoV-2 testing the day after the patient's initial positive test, as well as 5 days later, which were all negative.

According to the initial treatment plan, a total of $3.7 \times 10^{6} \%$ $\mathrm{kg}$ bodyweight CD34 positive autologous stem cells were administered on 'day 0'. Over the following days during severe neutropenia, the patient continued to lack COVID-19 specific symptoms.

On 'day +4 ' the patient developed a fever and CRP values started to rise. CXR was repeated but still didn't show any COVID-19 specific changes (Fig. 1B). Blood- and urinecultures were both positive for pseudomonas multidrug resistant gram-negative bacteria (MDRGN). Antibiotics were switched according to antibiotic susceptibility testing and fever and CRP values declined over the following days. Nasopharyngeal swabs were taken every other day and 
A

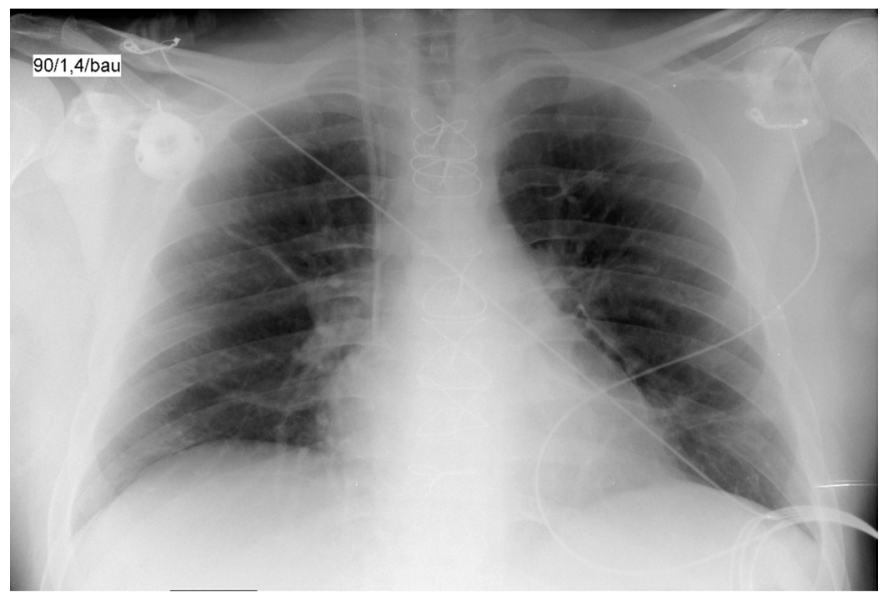

B

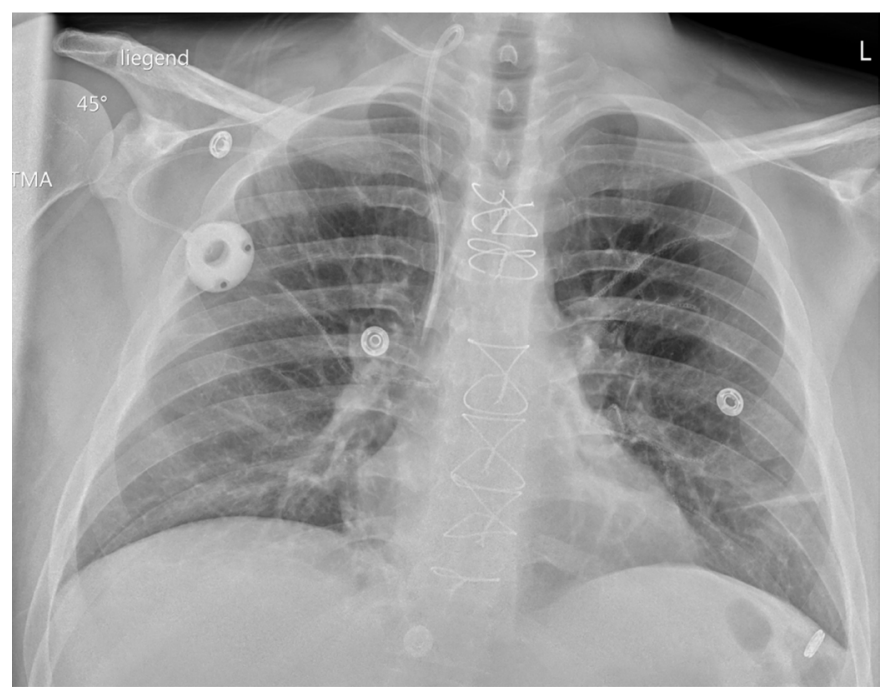

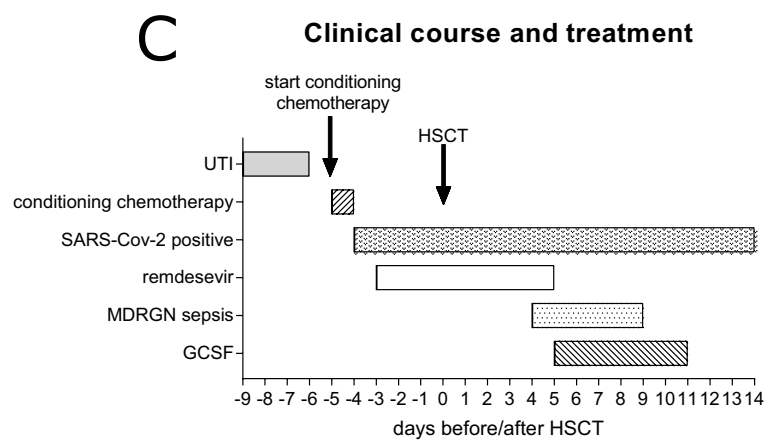

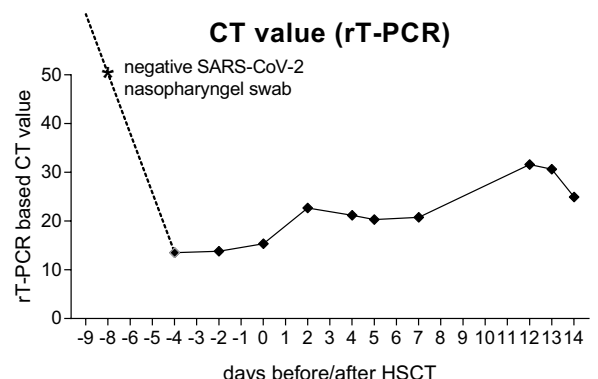

WBC (G/L)

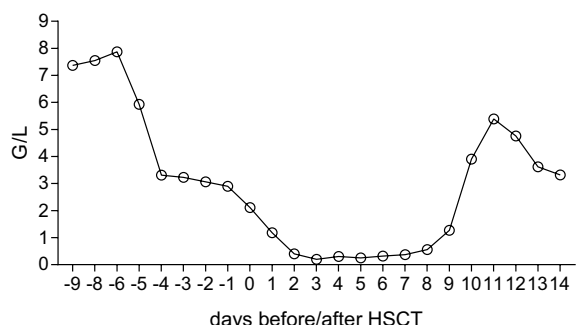

temperature $\left({ }^{\circ} \mathrm{C}\right)$

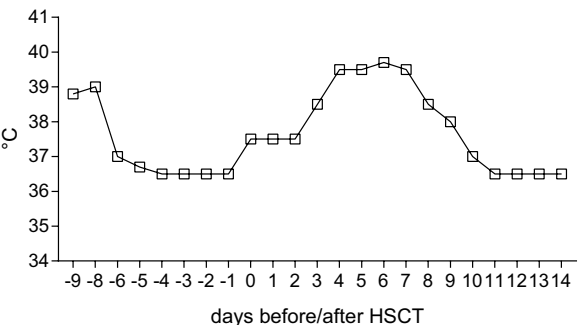

$\operatorname{CRP}(\mathrm{mg} / \mathrm{dl})$

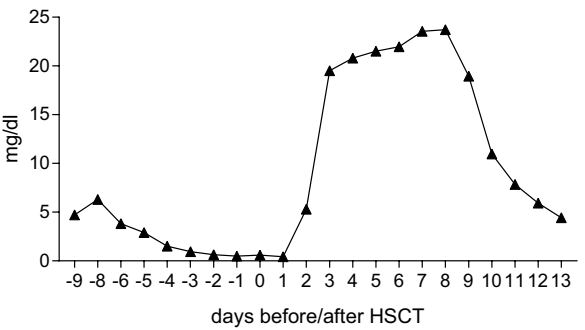

threshold cycle (ct) values, white blood count (WBC), body temperature (Celsius) and C-reactive protein (CRP). Days in relation hematopoietic stem cell transplant (HSCT) are presented on the X-axis with 'day 0 ' being the day of transplant 
Table 1 Characteristics of the case presented in this manuscript and previous cases of HSCT recipients diagnosed with COVID-19 during severe neutropenia before bone marrow engraftment. Cases presented include our case with testicular non-seminomatous germ cell tumor (NSGCT), one patient with Acute Myeloid Leukemia (AML), one patient with Acute Lymphoid Leukemia (ALL), one patient with
Chronic Lymphocytic Leukemia (CLL) and one patient with Multiple myeloma (MM). Patients received either reduced intensity conditioning (RIC) or myeloablative conditioning (MAC) before undergoing allogeneic (allo) or autologous (auto) hematopoietic stem cell transplantation (HSCT)

\begin{tabular}{|c|c|c|c|c|c|c|c|c|c|}
\hline Reference & Age (yrs) & Gender & $\begin{array}{l}\text { Underlying } \\
\text { malignancy }\end{array}$ & Type of HSCT & $\begin{array}{l}\text { Intensity of } \\
\text { conditioning } \\
\text { regimen }\end{array}$ & $\begin{array}{l}\text { Day of } \\
\text { COVID-19 } \\
\text { diagnosis in } \\
\text { relation to } \\
\text { HSCT }\end{array}$ & $\begin{array}{l}\text { COVID } \\
\text { related treat- } \\
\text { ment }\end{array}$ & $\begin{array}{l}\text { Need of respir- } \\
\text { atory support }\end{array}$ & Outcome \\
\hline Presented case & 33 & $\mathrm{~m}$ & NSGCT & auto & MAC & day -4 & Remdesivir & None & Survived \\
\hline $\begin{array}{l}\text { Kannelopoulos } \\
\text { et al. [8] }\end{array}$ & 64 & $\mathrm{~m}$ & AML & allo & RIC & day +6 & $\begin{array}{l}\text { Hyroxychloro- } \\
\text { quine }\end{array}$ & $\begin{array}{l}\text { No details } \\
\text { provided }\end{array}$ & Survived \\
\hline $\begin{array}{l}\text { Malek et al. } \\
\text { [9] }\end{array}$ & 61 & $\mathrm{~m}$ & MM & auto & MAC & day +3 & $\begin{array}{l}\text { Tocilizumab, } \\
\text { dexametha- } \\
\text { sone }\end{array}$ & None & Survived \\
\hline $\begin{array}{l}\text { Malek et al. } \\
\text { [9] }\end{array}$ & 69 & $\mathrm{~m}$ & CLL & allo & RIC & day +13 & $\begin{array}{l}\text { Convalescent } \\
\text { plasma, } \\
\text { tocilizumab, } \\
\text { anakinra, } \\
\text { remdesivir, } \\
\text { corticoster- } \\
\text { oids }\end{array}$ & $\begin{array}{l}\text { Mechanical } \\
\text { ventilation }\end{array}$ & Deceased \\
\hline
\end{tabular}

RT-PCR-based testing continued to yield $\mathrm{Ct}$ values $<30$ (Fig. 1C).

Starting on 'day + 5', GCSF 48Mio IE QD were administered until full WBC engraftment on day +10 . Throughout the engraftment phase the patient continued to lack any COVID-19 specific symptoms but Ct-values were still $<30$. According to reports showing prolonged viral shedding in immunocompromised patients [7], virus cultures were performed on nasopharyngeal swab samples, which yielded no cultivable virus on 'day +14 '. The patient was finally discharged on 'day +16 ' after transplant. SARS-CoV-2 IgG specific antibody testing during a routine follow-up visit showed an antibody response with $7 \mathrm{BAU} / \mathrm{ml}$ (negative if $<0.79 \mathrm{BAU} / \mathrm{ml}$ ).

So far, only three adult COVID-19 cases have been described in HSCT recipients in the pre-engraftment phase (Table 1) [8,9]. This is possibly due to stringent measures taken by transplant centers to prevent SARS-CoV-2 infections in this highly vulnerable patient population [10]. Our center requires a negative SARS-CoV-2 RT-PCR test done within $24 \mathrm{~h}$ before admission. Further, only one visitor once a week is allowed, who must provide a negative SARS-CoV-2 test result not older than $24 \mathrm{~h}$ regardless of vaccination status. All personnel are required to wear FFP2 masks at all times and are routinely tested once per week. However, and as our case shows, sometimes even these stringent precautions cannot prevent SARS-CoV-2 infection on a transplant unit. Our patient admitted to having had unprotected exposure to family/friends within the 12-day period between his first and second transplant. This was thought to be the most likely source of infection. Thus, we believe that home isolation prior to admission as recommended by the EBMT should strongly be emphasized and repeatedly be discussed with the patient at pre-transplant visits. Further, it might also be beneficial not only to do SARS-CoV-2 RT-PCR-based testing on the day of admission, but also a few days prior and after admission in order to detect patients in possible SARSCoV-2 incubation period, where RT-PCR might not yield a positive result yet.

Availability of data and material Not applicable.

Code availability Not applicable.

\section{Declarations}

Ethics approval and consent to participate All procedures performed in this case report were performed in accordance with the principles of the Declaration of Helsinki. Ethical approval was waived by the local Ethics Committee of the Medical University of Vienna in view of the retrospective nature of the case report and all the procedures being performed were part of routine care.

Consent for publication The participant has consented to the submission of the case report to the journal.

Conflict of interest The authors declare no competing interests. 


\section{References}

1. Piñana JL, Martino R, García-García I, Parody R, Morales MD, Benzo G et al (2020) Risk factors and outcome of COVID-19 in patients with hematological malignancies. Exp Hematol Oncol 9:21

2. Shah GL, DeWolf S, Lee YJ, Tamari R, Dahi PB, Lavery JA et al (2020) Favorable outcomes of COVID-19 in recipients of hematopoietic cell transplantation. J Clin Investig 130(12):6656-6667

3. Sharma A, Bhatt NS, St Martin A, Abid MB, Bloomquist J, Chemaly RF et al (2021) Clinical characteristics and outcomes of COVID-19 in haematopoietic stem-cell transplantation recipients: an observational cohort study. Lancet Haematol 8(3):e185-e193

4. Varma A, Kosuri S, Ustun C, Ibrahim U, Moreira J, Bishop MR et al (2020) COVID-19 infection in hematopoietic cell transplantation: age, time from transplant and steroids matter. Leukemia 34(10):2809-2812

5. Adra N, Abonour R, Althouse SK, Albany C, Hanna NH, Einhorn LH (2017) High-dose chemotherapy and autologous peripheralblood stem-cell transplantation for relapsed metastatic germ cell tumors: the Indiana University Experience. J Clin Oncol 35(10):1096-1102

6. Beigel JH, Tomashek KM, Dodd LE, Mehta AK, Zingman BS, Kalil AC et al (2020) Remdesivir for the treatment of Covid-19 — final report. N Engl J Med 383(19):1813-1826
7. Aydillo T, Gonzalez-Reiche AS, Aslam S, van de Guchte A, Khan Z, Obla A et al (2020) Shedding of viable SARS-CoV-2 after immunosuppressive therapy for cancer. N Engl J Med 383(26):2586-2588

8. Kanellopoulos A, Ahmed MZ, Kishore B, Lovell R, Horgan C, Paneesha $S$ et al (2020) COVID-19 in bone marrow transplant recipients: reflecting on a single centre experience. $\mathrm{Br} \mathrm{J}$ Haematol 190(2):e67-e70

9. Malek AE, Adachi JA, Mulanovich VE, Sassine J, Raad II, McConn $\mathrm{K}$ et al (2021) Immune reconstitution and severity of COVID-19 among hematopoietic cell transplant recipients. Transplant Infect Dis 23:e13606

10. Ljungman P, Mikulska M, de la Camara R, Basak GW, Chabannon C, Corbacioglu S et al (2020) The challenge of COVID-19 and hematopoietic cell transplantation; EBMT recommendations for management of hematopoietic cell transplant recipients, their donors, and patients undergoing CAR T-cell therapy. Bone Marrow Transplant 55(11):2071-2076

Publisher's note Springer Nature remains neutral with regard to jurisdictional claims in published maps and institutional affiliations. 